\title{
Osmoregulatory capacity of the shrimp Litopenaeus vannamei at different temperatures and salinities, and optimal culture environment
}

\author{
L. Fernando Bückle*, Benjamín Barón \& Mónica Hernández \\ Departamento de Acuicultura, Centro de Investigación Científica y Educación Superior de Ensenada (CICESE). \\ Apdo. 2732, 22800 Ensenada, Baja California, México. P.O. Box 434844, San Diego, Ca. 92143-4844 USA. Tel: \\ (52-61) 175-0500, Tel./Fax: (61) 75-05-34. *Corresponding author: fbuckle@cicese.mx
}

Received 16-IX-2005. ～C Corrected 22-II-2006. $\quad$ Accepted 23-V-2006.

\begin{abstract}
Osmoregulation in Litopenaeus vannamei was studied in a factorial experiment at four temperatures (20, 24, 28 and $32{ }^{\circ} \mathrm{C}$ ) and six salinities (10, 16, 22, 28, 34 and $40 \%$ ). The isosmotic related points for 20, 24, 28, and $32{ }^{\circ} \mathrm{C}$ were $754,711,822$, and $763 \mathrm{mmol} / \mathrm{kg}$, respectively. This species hyperregulates between at salinities of 10 and $20 \%$ and hyporegulates between 20 and $40 \%$. The isosmotic point in L. vannamei exposed to constant salinities changed in relation to temperature from 717 to $823 \mathrm{mmol} / \mathrm{kg}$. For these experimental conditions, the T-S combination of $32{ }^{\circ} \mathrm{C}$ and $28 \%$ produced the best growth. Rev. Biol. Trop. 54 (3): 745-753. Epub 2006 Sept. 29.
\end{abstract}

Key words: Physiology, salinity-temperature, shrimp culture, Litopenaeus vannamei.

Litopenaeus vannamei is the most important commercially farmed shrimp species in the western hemisphere. It is distributed in the Eastern Pacific rim from the State of Sonora Mexico, to Tumbes in Northern Peru (PerezFarfante and Kensley 1997). It inhabits the muddy bottoms of the coastline to a depth of approximately $70 \mathrm{~m}$ (Dore and Frimodt 1987). This species matures and spawns in the waters of the tropical coasts; the planktonic postlarvae migrate to the estuaries where they remain up to a total length of 10 to 20 $\mathrm{mm}$. While in the estuaries juveniles tolerate wide variations in temperature and salinity (Wickins 1976).

In order for juvenile shrimp to cope with salinity variations they must have the capability to regulate the concentration of haemolymph in spite of external salinity variations which may range from hypersaline to fresh water as reported for Litopenaeus setiferus, Farfantepenaeus aztecus and F. duorarum (Gunter and Shell 1958, Tabb et al. 1962,
Gunter and Hall 1963). For L. vannamei cultivated extensively or intensively, it is important to maintain the optimum temperature and salinity in order to obtain a maximum production. Techniques have been reported for shrimp reared from low salinities to marine environment. Such methods are summarized for L. stylirostris and $L$. vannamei pond culture involving pond water quality productivity and feeding (Hernandez and Villareal 1999, Jory and Dixon 2000). Complete control is practically impossible to attain due to the natural environmental fluctuations. However, sites can be selected for a range of salinity and temperature.

Under pond production conditions temperature is difficult to control, salinity can be adjusted using different sources of water or through water exchange. In contrast, shrimp culture in recirculating systems allows a major control of temperature and salinity and has become a very important issue to control the culture and in order to protect the environment by water discharge treatment. 
Research of the effects taken place by different combinations of salinity and temperature on the physiological responses of crustaceans have been centered in species of commercial importance. Temperature affects the osmotic characteristics of fluids, particularly in living systems by influencing water movements across cell membranes and in the uptake and loss of ions (Vernberg and Silverthorn 1979).

Mantel and Farmer (1983) and Péqueux (1995) review, state that "Osmoregulation, which is one of the most important regulatory functions an aquatic animal has to perform, has been extensively studied in many crustaceans". Lignot et al. (2000) consider that osmoregulation might also be considered in aquaculture in the early detection of adverse rearing conditions from different origins, including water quality. It constitutes an important energy expense to maintain in their body solute concentrations constant in an environment that changes, as it happens in shrimp pond cultivation.

To know the temperature and salinity effect on the physiology of shrimp it is necessary to evaluate the osmoregulatory capacity (OC), which was defined by Charmantier et al. (1989) as the difference between the osmotic pressures of the hemolymph and of the external medium, at a given salinity. Consequently several researches have been centered to find the isosmotic point, where the organism doesn't use the energy for osmoregulation and therefore it channels it to growth. This research evaluated the osmoregulatory responses in $L$. vannamei exposed to different temperatures and salinities to find the isosmotic point that reflects the condition for optimum growth in controlled conditions.

\section{MATERIALS AND METHODS}

Shrimp were acquired from a "Genesis" aquaculture facility in the State of Sonora, Mexico (28 $\left.48^{\prime} \mathrm{N}, 112^{\circ} 00^{\prime} \mathrm{W}\right)$. Postlarvae of $0.09-0.24 \mathrm{~g}$ were maintained in $1500 \mathrm{l}$ reservoirs with seawater $\left(24 \pm 1^{\circ} \mathrm{C}\right.$; $34 \pm 1 \%$; $6.5 \pm 1 \mathrm{mg} \mathrm{I}^{-1} \mathrm{O}_{2}$ ) during three months. The seawater was re-circulated through a biological filter, mechanical filter filled with silica sand, zeolite filters and an ultraviolet light system. Additionally, all tanks where aerated and shrimp were fed daily ad libitum with Camaronina (35\% protein), a diet formulated by Purina Company, Mexico.

After the shrimp reached the adequate size for haemolimph extraction (59.8 $\pm 0.82 \mathrm{~mm}$ T.L. and $1.64 \pm 0.06 \mathrm{~g}$ ), 500 shrimp were apportioned to four circular reservoirs of $400 \mathrm{I}$ each, in order to acclimate them at 20, 24, 28 and $32 \pm 1{ }^{\circ} \mathrm{C}$ during one month. The temperature $\left( \pm 1^{\circ} \mathrm{C}\right)$ was controlled with 1000 watt stainless steel heaters, each regulated with an electronic unit. The salinity was maintained at $34 \pm 1 \%$ with a continuous re-circulating water exchange. Each reservoir was aerated with air stones. Shrimps were exposed to the natural winter photoperiod.

After temperature acclimation, shrimp were transferred from the $400 \mathrm{l}$ tanks (34\%) to $40 \mathrm{l}$ aquariums in the laboratory. In order to avoid osmotic shock, the change of the water salinity was $6 \%$ per day until the factorial experiment of six salinities $(10,16,22,28$, 34 and $40 \%$ ) and four temperatures (20, 24, 28 and $32{ }^{\circ} \mathrm{C}$ ) was completed. The different water salinity concentrations were obtained by the addition of Fritz Super Salt Concentration (Made in the USA). A total of 24 groups of 20 shrimp per group were apportioned and chosen at random $(\mathrm{N}$ total $=480)$. Once the adjustment to the desired temperature and salinity was completed, the shrimp remained for an additional seven days period for full acclimation. This procedure was recommended by Weber and Spaargaren (1970) for Crangon crangon shrimp. Every day, the dissolved oxygen content in the aquariums was measured with an oxygen meter (YSI 50B, $0.01 \mathrm{mg} \mathrm{l}^{-1}$ ), the temperature with a thermometer $\left( \pm 0.1^{\circ} \mathrm{C}\right)$ and the salinity with a temperature compensated refractometer (Vista, A366ATC, $\pm 1 \%$ ). Once the measurements were made, salinity was reestablished to the required levels by adding tap water or brine at the required salinity. All aquariums where aerated through a hydro 
sponge filter acting as mechanical and biological filter that was cleaned every other day. The laboratory photoperiod was controlled by a 12L: 12D electronic timer with 30 min transition period between them. The shrimp were fed at $5 \%$ of the wet weight per day. Faeces and unconsumed food were removed from the aquariums on a daily basis.

The haemolymph osmotic pressure (OP) of each of the specimens was measured at the end of the acclimation period for the different salinity/temperature combinations. Using a pipette, puncture was made in the abdominal membrane, which was previously dried with absorbent paper to prevent contamination of the haemolymph with water. A ten $\mu$ sample of haemolymph was obtained from each shrimp. The sample was analyzed in a Wescor 5500 vapor osmometer and the data expressed in $\mathrm{mmol} / \mathrm{kg}$. The osmometer was recalibrated between each T-S haemolymph group measurement. By observing the uropods only intermolting specimens were sampled (Robertson et al. 1987). Each sampled shrimp was weighed (Ohaus balance $\pm 0.001 \mathrm{~g}$ ) after haemolimph sampling and total length measured with a ruler (mm) from the tip of the rostrum to the telson.

The data for the osmotic pressure of $L$. vannamei were normalized with the square root function and compared by a two-way analysis of variance. Multiple comparisons were done with the Tukey test. Measurements of the osmotic concentration in shrimp haemolymph were adjusted with polynomial functions (Zar 1984) and the isosmotic point was calculated in the intersection with the line of equality. The final weight and total length of the shrimp exposed for seven days at the temperaturesalinity combinations were compared with the Dunn's Method (Zar 1984).

\section{RESULTS}

During the seven days when L. vannamei individuals were exposed to different temperature-salinity combinations; the temperature, salinity and dissolved oxygen were stable (Table 1). Dissolved oxygen concentration of the experiments changed with water

TABLE 1

Mean water temperature $\left({ }^{\circ} \mathrm{C}\right)$, salinity (\%) and oxygen $(\mathrm{mg} / \mathrm{l})$ of Litopenaeus vannamei exposed for seven days to different temperature-salinity combinations (T-S)

$\begin{array}{cccccccc}\begin{array}{c}\text { Combination } \\ \text { T-S }\end{array} & \begin{array}{c}\text { Temperature } \\ \pm \mathrm{SE}\end{array} & \begin{array}{c}\text { Salinity } \\ \pm \mathrm{SE}\end{array} & \begin{array}{c}\text { Oxygen } \\ \pm \mathrm{SE}\end{array} & \begin{array}{c}\text { Combination } \\ \mathrm{T}-\mathrm{S}\end{array} & \begin{array}{c}\text { Temperature } \\ \pm \mathrm{SE}\end{array} & \begin{array}{c}\text { Salinity } \\ \pm \mathrm{SE}\end{array} & \begin{array}{c}\text { Oxygen } \\ \pm \mathrm{SE}\end{array} \\ 20-10 & 19.8 \pm 0.1 & 10 \pm 0.2 & 8.3 \pm 0.07 & 28-10 & 27.9 \pm 0.1 & 10 \pm 0.1 & 6.7 \pm 0.15 \\ 20-16 & 19.8 \pm 0.1 & 15 \pm 0.2 & 7.2 \pm 0.40 & 28-16 & 27.9 \pm 0.1 & 16 \pm 0.3 & 6.4 \pm 0.17 \\ 20-22 & 20.1 \pm 0.2 & 22 \pm 0.3 & 7.3 \pm 0.10 & 28-22 & 27.9 \pm 0.1 & 22 \pm 0.3 & 5.8 \pm 0.15 \\ 20-28 & 19.8 \pm 0.1 & 28 \pm 0.2 & 6.6 \pm 0.26 & 28-28 & 28.1 \pm 0.1 & 28 \pm 0.3 & 4.7 \pm 0.32 \\ 20-34 & 19.8 \pm 0.1 & 34 \pm 0.4 & 6.5 \pm 0.25 & 28-34 & 28.1 \pm 0.1 & 34 \pm 0.3 & 4.9 \pm 0.23 \\ 20-40 & 19.9 \pm 0.1 & 40 \pm 0.4 & 6.3 \pm 0.22 & 28-40 & 28.2 \pm 0.1 & 40 \pm 0.4 & 4.8 \pm 0.12 \\ 24-10 & 24.1 \pm 0.2 & 10 \pm 0.2 & 7.3 \pm 0.13 & 32-10 & 31.9 \pm 0.1 & 10 \pm 0.1 & 6.2 \pm 0.15 \\ 24-16 & 24.3 \pm 0.1 & 15 \pm 0.2 & 6.4 \pm 0.50 & 32-16 & 31.6 \pm 0.1 & 15 \pm 0.3 & 5.9 \pm 0.15 \\ 24-22 & 24.3 \pm 0.1 & 22 \pm 0.3 & 6.5 \pm 0.06 & 32-22 & 31.3 \pm 0.1 & 22 \pm 0.4 & 5.2 \pm 0.22 \\ 24-28 & 24.3 \pm 0.2 & 28 \pm 0.1 & 6.1 \pm 0.13 & 32-28 & 31.8 \pm 0.1 & 27 \pm 0.2 & 4.8 \pm 0.24 \\ 24-34 & 24.2 \pm 0.2 & 34 \pm 0.3 & 5.7 \pm 0.12 & 32-34 & 31.7 \pm 0.1 & 34 \pm 0.3 & 4.9 \pm 0.14 \\ 24-40 & 24.2 \pm 0.1 & 40 \pm 0.3 & 5.6 \pm 0.10 & 32-40 & 31.9 \pm 0.2 & 40 \pm 0.3 & 4.6 \pm 0.10\end{array}$

( \pm SE) Standard error. Nine observations for each T-S combination. 
temperature and salinity. The mean dissolved oxygen concentration for 20, 24, 28 and $32{ }^{\circ} \mathrm{C}$ were $7.0,6.3,5.5$ and $5.3 \mathrm{mg} \mathrm{l}^{-1}$, respectively (Table 1).

The final weight and total length of the shrimp that were acclimated at 20, 24, 28 and $32 \pm 1{ }^{\circ} \mathrm{C}$; and exposed for seven days at the temperature-salinity combinations were significantly different $(\mathrm{p}<0.05)$. The pairwise multiple comparisons (Dunn's Method) indicate that the weight and total length of the organisms acclimated at $20^{\circ} \mathrm{C}$ were significantly different $(\mathrm{p}<0.05)$ compared to treatments of 24, 28 and $32{ }^{\circ} \mathrm{C}$ (Table 2). The means of total length and wet weight (including all salinities) at $20^{\circ} \mathrm{C}$ were $59.5 \mathrm{~mm}( \pm 1.93 \mathrm{SE})$ and $1.58 \mathrm{~g}$ $( \pm 0.14 \mathrm{SE})$; at $24^{\circ} \mathrm{C}, 64.8 \mathrm{~mm}( \pm 1.90 \mathrm{SE})$ and $2.05 \mathrm{~g}( \pm 0.17 \mathrm{SE})$; at $28^{\circ} \mathrm{C}, 64.6 \mathrm{~mm}( \pm 2.53$ $\mathrm{SE})$ and $2.25 \mathrm{~g}( \pm 0.28 \mathrm{SE})$ and at $32^{\circ} \mathrm{C}, 67.8$ $\mathrm{mm}( \pm 3.00 \mathrm{SE})$ and $2.58 \mathrm{~g}( \pm 0.34 \mathrm{SE})$.

The OP in the $L$. vannamei haemolymph when exposed to four temperatures and six salinities are shown in Fig. 1, 2. The points where the OP of the haemolymph crosses the isosmotic line were $763 \mathrm{mmol} / \mathrm{kg}$ for $20^{\circ} \mathrm{C}$;
$717 \mathrm{mmol} / \mathrm{kg}$ for $24{ }^{\circ} \mathrm{C}$; $823 \mathrm{mmol} / \mathrm{kg}$ for $28{ }^{\circ} \mathrm{C}$ and $768 \mathrm{mmol} / \mathrm{kg}$ for $32^{\circ} \mathrm{C}$. The isosmotic point varies in relation to temperature, it decreased $46 \mathrm{mmol} / \mathrm{kg}$ between 20 and $24{ }^{\circ} \mathrm{C}$ and increased $106 \mathrm{mmol} / \mathrm{kg}$ when the temperature was increased to $28^{\circ} \mathrm{C}$ and decreased 55 $\mathrm{mmol} / \mathrm{kg}$ at $32{ }^{\circ} \mathrm{C}$ (Table 3). The difference between the lowest $\left(24^{\circ} \mathrm{C}\right)$ and the highest isosmotic pressure $\left(28^{\circ} \mathrm{C}\right)$ in terms of salinity was $3.5 \%$.

\section{DISCUSSION}

Chen et al. (1995) studied the survival, growth and osmolality of the haemolymph and the water content in the tissues of Fenneropenaeus chinensis juveniles, concluding that the osmolality of the haemolymph increased with an increase in salinity, and decreased with an increase in temperature. The results of this study indicate that $L$. vannamei does not follow that pattern with regards to temperature. The shrimp used in this research regulated the osmotic pressure of the haemolymph

TABLE 2

Final mean total length $(\mathrm{mm})$ and body weight $(\mathrm{g})$ of Litopenaeus vannamei first acclimated for thirty days at different temperatures and afterward seven days at different temperature-salinity combinations (T-S)

$\begin{array}{cccccccccc}\begin{array}{c}\text { Temperature } \\ \left({ }^{\circ} \mathrm{C}\right)\end{array} & \begin{array}{c}\text { Salinity } \\ (\%)\end{array} & \mathrm{N} & \begin{array}{c}\text { Length } \\ \pm \mathrm{SE}\end{array} & \begin{array}{c}\text { Body weight } \\ \pm \mathrm{SE}\end{array} & \begin{array}{c}\text { Temperature } \\ \left({ }^{\circ} \mathrm{C}\right)\end{array} & \begin{array}{c}\text { Salinity } \\ (\%)\end{array} & \begin{array}{c}\text { Length } \\ \pm \mathrm{SE}\end{array} & \begin{array}{c}\text { Body weight } \\ \pm \mathrm{SE}\end{array} \\ 20 & 10 & 15 & 56 \pm 3.0 & 1.1 \pm 0.09 & 28 & 10 & 15 & 64 \pm 1.9 & 2.1 \pm 0.19 \\ 20 & 16 & 15 & 60 \pm 1.5 & 1.8 \pm 0.18 & 28 & 16 & 9 & 62 \pm 3.7 & 2.6 \pm 0.57 \\ 20 & 22 & 15 & 60 \pm 2.1 & 1.8 \pm 0.21 & 28 & 22 & 15 & 62 \pm 2.1 & 1.8 \pm 0.21 \\ 20 & 28 & 16 & 63 \pm 1.8 & 1.8 \pm 0.16 & 28 & 28 & 15 & 69 \pm 2.0 & 2.6 \pm 0.21 \\ 20 & 34 & 20 & 60 \pm 1.6 & 1.5 \pm 0.14 & 28 & 34 & 16 & 61 \pm 2.5 & 1.9 \pm 0.23 \\ 20 & 40 & 15 & 58 \pm 1.6 & 1.5 \pm 0.11 & 28 & 40 & 15 & 70 \pm 3.0 & 2.5 \pm 0.31 \\ 24 & 10 & 13 & 62 \pm 2.7 & 1.9 \pm 0.23 & 32 & 10 & 15 & 68 \pm 4.1 & 2.7 \pm 0.54 \\ 24 & 16 & 15 & 66 \pm 1.7 & 2.1 \pm 0.16 & 32 & 16 & 18 & 67 \pm 2.5 & 2.4 \pm 0.27 \\ 24 & 22 & 15 & 67 \pm 1.5 & 2.1 \pm 0.15 & 32 & 22 & 13 & 67 \pm 2.5 & 2.5 \pm 0.27 \\ 24 & 28 & 14 & 64 \pm 2.5 & 2.1 \pm 0.25 & 32 & 28 & 13 & 75 \pm 2.1 & 3.2 \pm 0.26 \\ 24 & 34 & 15 & 67 \pm 1.1 & 2.2 \pm 0.13 & 32 & 34 & 15 & 63 \pm 3.7 & 2.2 \pm 0.37 \\ 24 & 40 & 15 & 63 \pm 1.9 & 1.9 \pm 0.14 & 32 & 40 & 15 & 67 \pm 3.1 & 2.5 \pm 0.35\end{array}$

Standard error $( \pm \mathrm{SE})$. 

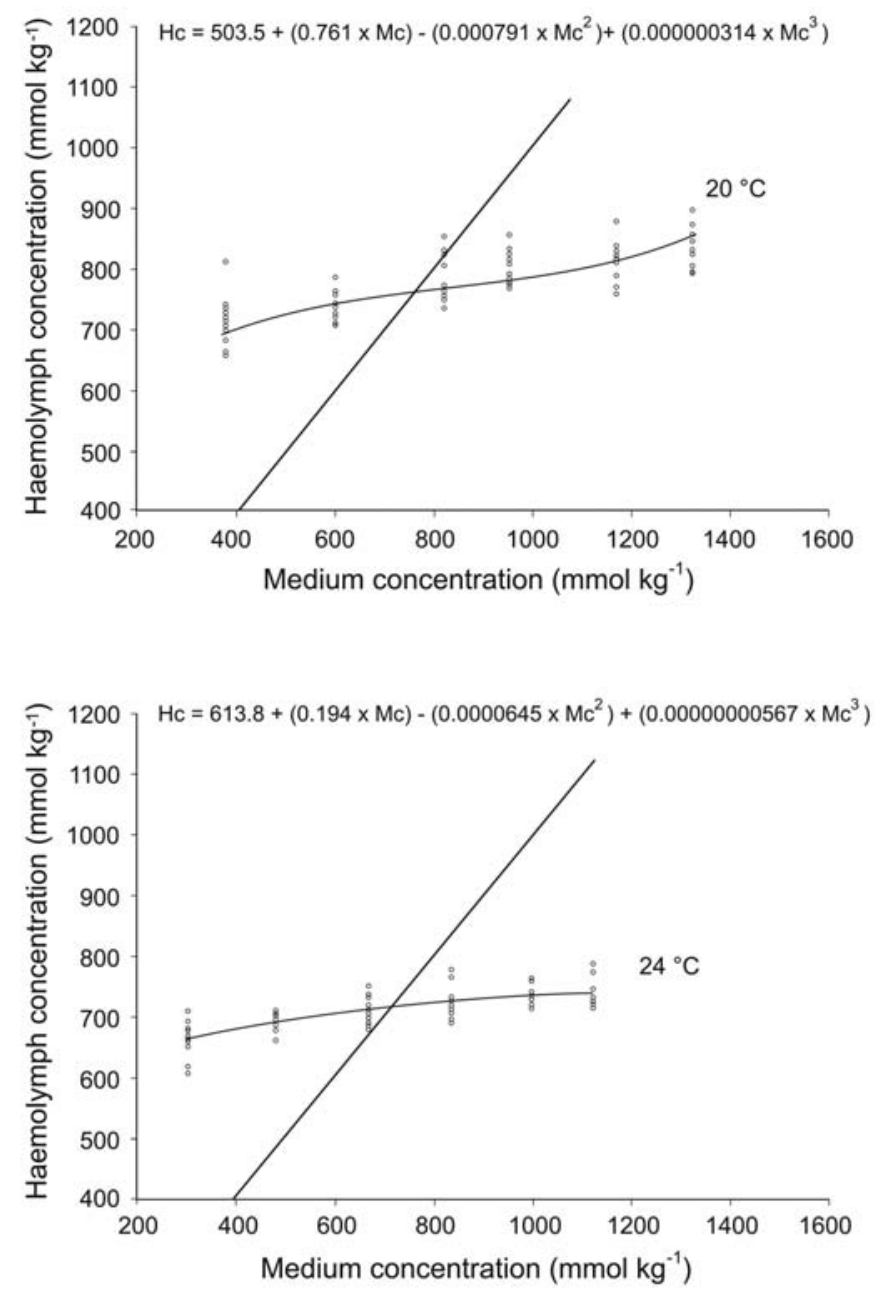

Fig. 1. Osmoregulation (mmol kg ${ }^{-1}$ ) of Litopenaeus vannamei exposed to 20 (top) and $24{ }^{\circ} \mathrm{C}$ (bottom). The intersection indicates the respective isosmotic point. The open circles depict each individual. Hc, haemolymph concentration $\left(\mathrm{mmol} \mathrm{kg}^{-1}\right)$; Mc, external medium concentration $\left(\mathrm{mmol} \mathrm{kg}^{-1}\right)$.

within a very narrow interval (hyper-hyporegulation) even when the salinity interval was 10 to $40 \%$ and the temperature interval 20 to $32{ }^{\circ} \mathrm{C}$. The isosmotic point in L. vannamei exposed to constant salinities changed in relation to temperature from 717 to $823 \mathrm{mmol} / \mathrm{kg}$. Castille and Lawrence (1981) reported an isosmotic point of $718 \mathrm{mOsm} \mathrm{kg}^{-1}$ in the same species when evaluated the effect of salinity on the osmotic concentration at $23^{\circ} \mathrm{C}$. Díaz et al. (2001) mention that juveniles exposed to osmotic stress at different temperatures experiences less stress in salinities close to the isosmotic point. Our results denote that the best T-S combination that could be used in L. vannamei cultivation is $28{ }^{\circ} \mathrm{C}$ and the isosmotic point of $823 \mathrm{mmol} / \mathrm{kg}$. However, considering the results of weight and total length, the major increment was observed at $32{ }^{\circ} \mathrm{C}$ (Table 2); the combination of salinities above $28 \%$ and temperatures from 28 to $32{ }^{\circ} \mathrm{C}$ could be a promising T-S combination that could apply in the culture of this species.

Diverse authors have studied the effect of temperature and salinity on the osmoregulatory capacity in species of commercial importance such as shrimps, with the purpose 

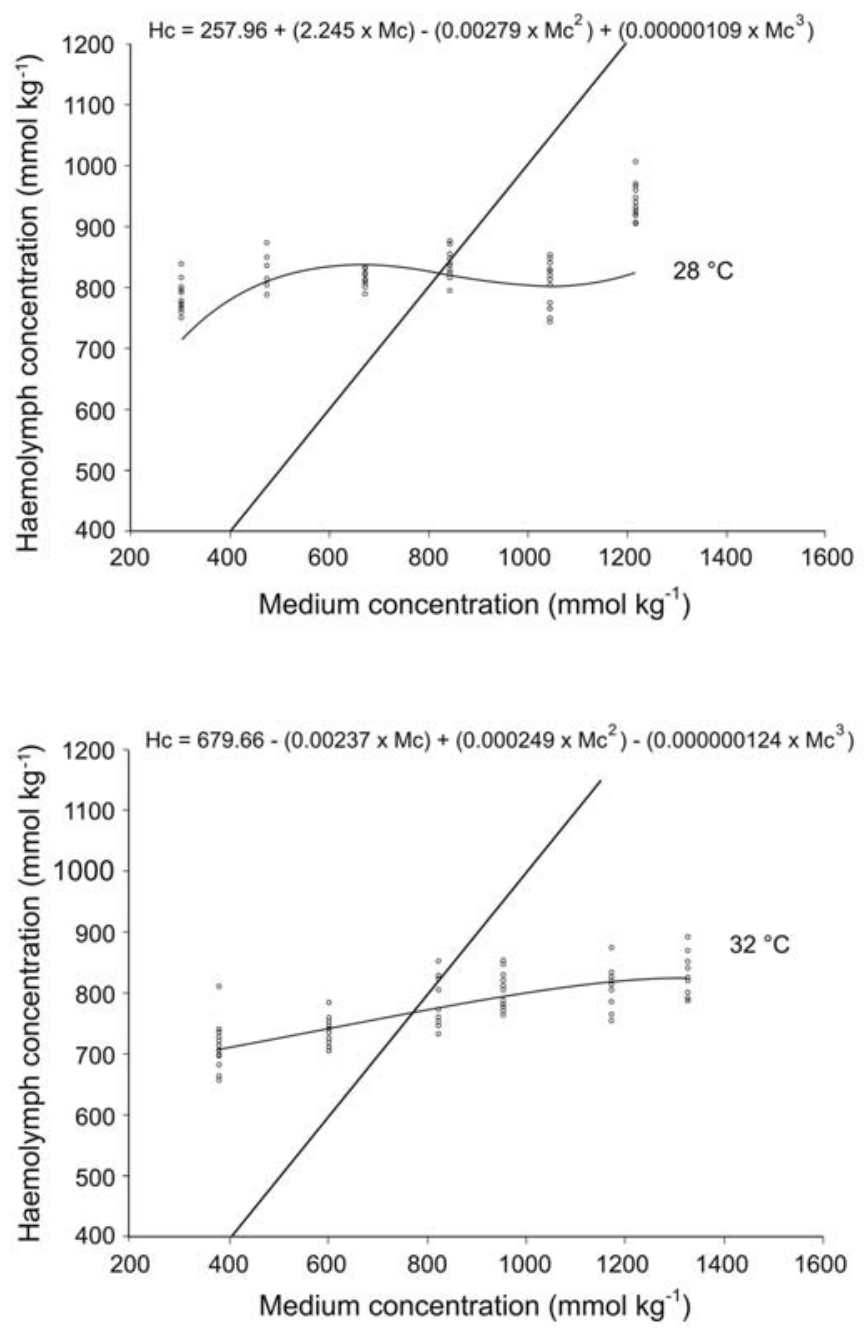

Fig. 2. Osmoregulation (mmol kg ${ }^{-1}$ ) of Litopenaeus vannamei exposed to 28 (top) and $32{ }^{\circ} \mathrm{C}$ (bottom). The intersection indicates the respective isosmotic point. The open circles depict each individual. Hc, haemolymph concentration $\left(\mathrm{mmol} \mathrm{kg}^{-1}\right)$; Mc, external medium concentration $\left(\mathrm{mmol} \mathrm{kg}^{-1}\right)$.

of establishing the optimal conditions and specifically the isosmotic point. In this sense, Charmantier et al. (1988) reported the salinity tolerance of Marsupenaeus japonicus and F. chinensis postlarvae finding the smallest rate of mortality when the haemolymph was isosmotic to seawater. In our study the mortality of juveniles exposed at different T-S combinations was $25-30 \%$, except in $28{ }^{\circ} \mathrm{C}$ and $16 \%$ (55\%) combination.

When $L$. vannamei was exposed to different combinations of temperature-salinity we found a change in osmotic pressure (OP) that was significantly different between 24 and $28{ }^{\circ} \mathrm{C}$, also reflected in the isosmotic point that changed in relation to temperature acclimation between 20 and $27 \%$. The OP of the shrimp at all temperatures was maintained between 664

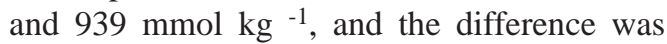
equivalent to $24.8 \%$ of the water salinity interval (10-40\%). The percentage between the maximum and minimum interval value of the OP compared with the external water salinity interval (1 $108 \mathrm{mmol} / \mathrm{kg}=100 \%)$ was $20.5 \%$ 
TABLE 3

Mean osmotic pressure $(\mathrm{mmol} / \mathrm{kg}$ ) of Litopenaeus vannamei exposed at different temperature-salinity combinations (T-S)

\begin{tabular}{|c|c|c|c|c|c|c|c|}
\hline $\begin{array}{c}\text { Combination } \\
\mathrm{T}-\mathrm{S}\end{array}$ & & $\mathrm{N}$ & $\begin{array}{c}\text { Osmotic pressure } \\
\pm \mathrm{SE}\end{array}$ & $\begin{array}{c}\text { Combination } \\
\text { T-S }\end{array}$ & & $\mathrm{N}$ & $\begin{array}{c}\text { Osmotic pressure } \\
\pm \mathrm{SE}\end{array}$ \\
\hline $20-10$ & $\mathrm{a}$ & 15 & $664 \pm 7$ & $28-10$ & $\mathrm{~b}$ & 15 & $783 \pm 6$ \\
\hline $20-16$ & $\mathrm{~b}$ & 15 & $716 \pm 5$ & $28-16$ & $\mathrm{a}$ & 8 & $825 \pm 9$ \\
\hline $20-22$ & $\mathrm{C}$ & 15 & $752 \pm 3$ & $28-22$ & $\mathrm{a}$ & 15 & $812 \pm 3$ \\
\hline $20-28$ & $\mathrm{c}$ & 15 & $745 \pm 4$ & $28-28$ & $\mathrm{a}$ & 15 & $839 \pm 5$ \\
\hline $20-34$ & $\mathrm{~d}$ & 15 & $797 \pm 8$ & $28-34$ & $a b$ & 15 & $804 \pm 9$ \\
\hline $20-40$ & $\mathrm{~d}$ & 15 & $792 \pm 6$ & $28-40$ & c & 15 & $939 \pm 6$ \\
\hline $24-10$ & $\mathrm{~d}$ & 13 & $667 \pm 7$ & $32-10$ & c & 15 & $709 \pm 9$ \\
\hline $24-16$ & cd & 15 & $690 \pm 3$ & $32-16$ & d & 16 & $737 \pm 5$ \\
\hline $24-22$ & bc & 15 & $715 \pm 5$ & $32-22$ & b & 13 & $778 \pm 10$ \\
\hline $24-28$ & $a b$ & 15 & $727 \pm 5$ & $32-28$ & $a b$ & 13 & $804 \pm 8$ \\
\hline $24-34$ & $a b$ & 15 & $737 \pm 3$ & $32-34$ & $\mathrm{a}$ & 15 & $811 \pm 7$ \\
\hline $24-40$ & $\mathrm{a}$ & 13 & $743 \pm 6$ & $32-40$ & $\mathrm{a}$ & 15 & $828 \pm 7$ \\
\hline
\end{tabular}

Different letters indicate significant differences at the same probability level $(\mathrm{p}<0.05)$. $\mathrm{N}=$ number of individuals. Standard error $( \pm \mathrm{SE})$.

for $20^{\circ} \mathrm{C} ; 16.8 \%$ for $24{ }^{\circ} \mathrm{C} ; 13.7 \%$ for $28{ }^{\circ} \mathrm{C}$ and $21.4 \%$ for $32{ }^{\circ} \mathrm{C}$. L. vannamei is an species which hyper-hyporegulates when exposed to salinities ranging from 10 to $40 \%$.

The osmoregulatory responses of $L$. vannamei juveniles may explain the adjustment to estuaries and coastal lagoons environments. Evaporation due to temperature effect is high, and salinity may vary from 40 to $50 \%$ and drop to $10 \%$ after the intense intermittent rainy season (Holtschmit and Romero 1991). Palafox et al. (1997) established that approximately 28 to $33^{\circ} \mathrm{C}$ and $40 \%$ is the best environmental culture conditions for survival and growth for this species.

A captive maturation survey in 1988 also indicated that $27-29^{\circ} \mathrm{C}$ and $28-32 \%$ were the most common "industry standards" in the Americas and Caribbean basin (Ogle 1991a, b). Wyban et al. (1995) mention that the optimal temperature for shrimp smaller than $5 \mathrm{~g}$ could be higher than $30^{\circ} \mathrm{C}$ and about $27^{\circ} \mathrm{C}$ for large shrimp. Our results, in accordance with these authors can be applied to pond cultures.
Survival and growth determines the good or poor performance of shrimp culture in closed systems. Barón et al. (2004) and Anaya (2005) successfully applied these results to intensive culture of $L$. vannnamei in recirculation seawater systems.

\section{ACKNOWLEDGMENTS}

This work was supported by the Federal Government of Mexico through regular funding of the Centro de Investigación Científica y Educación Superior de Ensenada (CICESE) and the Consejo Nacional de Ciencia y Tecnología (CONACYT), grant: 4050P-B.

\section{RESUMEN}

La respuesta osmorreguladora de Litopenaeus vannamei se estudió en un experimento factorial con cuatro temperaturas $\left(20,24,28\right.$ y $\left.32{ }^{\circ} \mathrm{C}\right)$ y seis salinidades $(10,16,22$, 28, 34 y $40 \%$ ). Los puntos isosmóticos relacionados para 20, 24, 28, y $32{ }^{\circ} \mathrm{C}$ fueron 754, 711, 822, y $763 \mathrm{mmol} / \mathrm{kg}$, 
respectivamente. Esta especie hiperregula dentro del intervalo de 10 y $20 \%$ e hiporegula entre 20 y $40 \%$. El punto isosmótico de $L$. vannamei expuesto a salinidades constantes cambia en relación a la temperatura desde 717 a $823 \mathrm{mmol} /$ kg. Para estas condiciones experimentales, la combinación T-S de $32{ }^{\circ} \mathrm{C}$ y $28 \%$ produjo el mejor crecimiento.

Palabras clave: Fisiología, salinidad-temperatura, cultivo de camarón, Litopenaeus vannamei.

\section{REFERENCES}

Anaya, R.R. 2005. Cultivo del camarón blanco,Litopenaeus vannamei, Boone (1931), en sistema cerrado a alta densidad. Tesis de Maestría. Centro de Investigación Científica y Educación Superior de Ensenada. 65 p.

Barón, B.S., R.L.F. Bückle \& R.M. Hernández. 2004. Intensive culture of Litopenaeus vannamei Boone 1931, in recirculating seawater system. Cien. Mar. 30: 179-188.

Castille, F.L. \& A.L. Lawrence. 1981. The effect of salinity on the osmotic and chloride concentration in the hemolymph of eurihaline shrimp of the genus Penaeus. Comp. Biochem. Physiol. 68: 75-85.

Charmantier, D.M., P. Thuet, G.P. Charmantier \& J. Trilles. 1988. Tolérance à la salinité et osmorégulation chez les post-larves de Penaeus japonicus et $P$. chinensis. Effet de la température. Aquat. Living Resour. 1: 267-276.

Charmantier G., N. Bouaricha, M. Charmantier-Daures, P. Thuet \& J.P. Trilles. 1989. Salinity tolerance and osmoregulatory capacity as indicators of the physiological state of peneid shrimps. Eur. Aquat. Soc. Spec. Publ. 10: 65-66.

Chen, J.C., M.N. Lin, Y.Y. Ting \& J.N. Lin. 1995. Survival, haemolymph osmolality and tissue water of Penaeus chinensis juveniles acclimated to different salinity and temperature levels. Comp. Biochem. Physiol. 110: 253-258.

Díaz, H., C. Farfán, E. Sierra \& A.D. Re. 2001. Effects of temperature and salinity fluctuation on the ammonium excretion and osmoregulation of juveniles of Penaeus vannamei, Boone 1931. Mar. Fresh. Behav. Physiol. 34: 93-104.

Dore, I. \& C. Frimodt. 1987. An Illustrated Guide to Shrimp of the World. Osprey Books, Huntington, New York, USA.

Gunter, G. \& W.E. Jr. Shell. 1958. A study of an estuarine area with water-level control in the Louisiana marsh. Proc. LA Acad. Sci. 21: 5-34.
Gunter, G. \& G.E. Hall. 1963. Biological investigations of the St. Lucie estuary (Florida) in connection with Lake Okeechobee discharges through the St. Lucie canal. Gulf Res. Rep. 1: 189-307.

Hernández, L.A. \& C.H. Villareal. 1999. TEMA a software reference to shrimp Litopenaeus vannamei farming practices. Aquacult. Econ. Manage. 3: 267-280.

Holtschmit, H.K. \& J.M. Romero. 1991. Maturation and spawning of blue shrimp Penaeus stylirostris (Stimpson) under hypersaline conditions. J. World Aquac. Soc. 22: 45-50

Jory, D.E. \& H.M. Dixon. 2000. General concerns for management of in progress shrimp ponds. Aquacult. Mag. 26: 76-80.

Lignot, J.H., C. Spanings-Pierrot \& G. Charmantier. 2000. Osmoregulatory capacity as a tool in monitoring the physiological condition and the effect of stress in crustaceans. Aquaculture 191: 209-245.

Mantel, L.H. \& L.L. Farmer. 1983. Osmotic and ionic regulation. The Biology of Crustacea, p. 53-161. In D.E. Bliss \& L.H. Mantel (eds.). Internal Anatomy and Physiological Regulations vol. 5 Academic, New York, New York, USA.

Ogle, T.J. 1991a. Design and operation of small tank system for ovarian maturation and spawning of Penaeus vannamei. Gulf Res. Rep. 8: 285-289.

Ogle, T.J. 1991b. Maturation of Penaeus vannamei based upon survey. Gulf Res. Rep. 8: 295-297.

Palafox, P.J., P.C.A. Martinez \& G.L. Ross. 1997. The effects of salinity and temperature on the growth and survival rates of juvenile white shrimp, Penaeus vannamei, Boone. 1931. Aquaculture 157: 107-115.

Péqueux, A. 1995. Osmotic regulation in crustaceans. J. Crustacean Biol. 15: 1-60.

Perez Farfante, I. \& B. Kensley. 1997. Penaeoid and Sergestoid shrimps and prawns of the World. Keys and Diagnoses for the Families and Genera. Mem. Mus. Natl. D`Hist. Nat. Paris, France. 233 p.

Robertson, L., W.A. Bray, J.L. Leung-Trujillo \& A. Lawrence. 1987. Practical molt staging of Penaeus setiferus and $P$. stylirostris. J. World Aquac. Soc. 18: 180-185.

Tabb, D.C., D.L. Dubrow \& R.B. Manning. 1962. The ecology of northern Florida Bay and adjacent estuaries. Fla. St. Bd. Conserv. Tech. Ser. 39: 1-79.

Vernberg, F.J. \& S.U. Silverthorn. 1979. Temperature and osmoregulation in aquatic species, p. 537-562. In R. Gilles (ed.). Mechanisms of Osmoregulation in Animals. Wiley, New York, New York, USA. 
Weber, R.E. \& D.H. Spaargaren. 1970. On the influence of temperature on the osmoregulation of Crangon crangon and its significance under estuarine conditions. Nether. J. Sea Res. 5: 108-120.

Wickins, J.F. 1976. Prawn biology and culture. Oceanogr. Mar. Biol. A. Rev. 14: 435-507.
Wyban, J., W.A. Walsh \& D.M. Godin. 1995. Temperature effects on growth, feeding rate and feed conversion of the Pacific white shrimp (Penaeus vannamei). Aquaculture. 138: 267- 279.

Zar, J.H. 1984. Biostatistical analysis. Prentice Hall. New Jersey, USA. 718 p. 
